\title{
AFRICAN-AMERICAN THEATER \& THE DECONSTRUCTION OF THE AMERICAN DREAM
}

\author{
Marcela lochem Valente ${ }^{1}$
}

\begin{abstract}
Lorraine Hansberry was an African-American playwright who used her plays as a way of protest against the injustice towards the African descendants in the USA and fought against the prejudice and discrimination faced by her people at that time. Her work was a site for many discussions that were very relevant to further movements such as the civil rights one. She showed in her work that although the USA was supposed to be the Land of Opportunity, the prosperity of this land as well as the ideals from the American Dream were not available the same way to all citizens, just to those who could fit the mainstream American stereotype. This article is going to show that Theater can be an important way of self-representation, a site for relevant discussions, and a way of subverting patriarchal discourses.
\end{abstract}

Key words: African-American Theater, American Dream, the Land of Opportunity, deconstruction, Lorraine Hansberry.

Resumo: Lorraine Hansberry foi uma escritora afro-americana que fez de suas peças uma forma de protesto contra as injustiças sofridas pelos descendentes africanos nos EUA além de lutar contra o preconceito e a discriminação vividos por seu povo. Sua obra foi palco para diversas discussões de grande relevância para movimentos que vieram a ocorrer posteriormente como por exemplo o movimento pelos direitos humanos. Ela mostrou que embora os EUA fossem vistos com a terra das oportunidades, a prosperidade desse país, assim como os ideais do Sonho Americano, não estavam disponíveis da mesma maneira para todos os cidadãos, mas apenas para aqueles que pudessem se enquadrar nos padrões tidos como americanos. Este artigo pretende mostrar que 0 Teatro pode ser uma importante forma de auto-representação, um local para discussões relevantes e uma oportunidade para a subversão de discursos patriarcais.

Palavras-chave: Teatro afro-americano, Sonho americano, Terra das oportunidades, Desconstrução, Lorraine Hansberry.

\section{AMERICAN THEATER: A GENERAL PANORAMA}

I said racism is a device that, of itself, explains nothing. It is simply a means. An invention to justify the rule of some men over others... (Lorraine Hansberry).

1 M estre em Letras: Literaturas de Língua Inglesa, pelo Programa de Pós-Graduação em Letras da Universidade do Estado do Rio de Janeiro - PPGLET/UERJ. Professora de Literaturas de Língua Inglesa no curso de letras inglês/português da Fundação Educacional de Duque de Caxias (FEUDUC). Endereço eletrônico: marcellaiv@ig.com.br. 
Theater is built upon devices. In the theatrical environment, the signification of objects results from their specific usage in the moment (Harry Elam \& David Krasner).

American Theater started without a national identity being just sort of an imitation of the English one and having as its basis the Shakespearean trends. But social, political and economical changes reshaped the theatrical practices along the time. Movements such as the Renaissance brought a real revolution to Theater and in about fifty years the dramatic movement was considerably changed (RICE, 1962, p. 140). After a while American Theater, instead of a mere copy of the English one, turned into a search for selfrepresentation. Elmer Rice states that there are some moments in history when social changes, historical facts and concerns of society lead to great artistic representation and according to him Renaissance was a period like that. Dramatists from this period were concerned about portraying the world in which they lived in and also the people who inhabited this world.

Another moments pointed by Rice as being responsible for many changes in Theater were the XIX and XX centuries. Some facts such as the Industrial Revolution, the Civil War as well as the Immigration Movements into the United States during this period were fundamental to the changes that took place in the theatrical practices. The immigrant's necessity of selfrepresentation, for example, considerably contributed to the changes in Theater. Members of different nationalities started to appear portraying characters from their original countries and cultures. Because of the new reality of the XX century, there was also a new search for national and cultural values that had been disregarded so far. As David M amet stated

\footnotetext{
[i]n the theater today we're beginning to recognize ourselves as Americans. In the sixties we rejected pride in being American. In the seventies the theater is saying that being American is nothing to be ashamed of. But we have to learn with it (BIGSBY, 1990, p. 274).
}

It is important to mention that the performance of the United States in joining the World War I had great influence in these changes as well. By "the great" performance that the country had during the war - according to the American mainstream point of view - they were able to show that the USA was not a pacific country cultivating their land anymore, but on the contrary, they had more power than they were expected to have. This fact made them look for self representation reevaluating some patterns followed so far, showing pride for their country and opening ways for subversive as well as nationalist works. According to Rice, this general self-criticism and insatisfaction with the national culture lead to a search for an art that questioned and challenged 102 A Cor das Letras - UEFS, n. 10, 2009 
the existent ideas and that could show a new and subversive way of expression (RICE, 1962, p. 147). And in this period of questioning and search for selfrepresentation we also had the minority groups trying to insert themselves into history by their art productions. They wanted to show their thoughts and feelings in relation to the land of opportunity and also the American Nightmare that many of them faced while searching for the American Dream. And they also wanted to produce Theater about themselves, by themselves and addressed to themselves because:

[t]here was no longer a single audience to be addressed, if in truth there ever had been. Now blacks, women, Chicanos, gays, Indians and Chinese addressed themselves, displayed an image of themselves bestriding in the stage, the central characters in their own drama rather than marginal figures in some national pageant. And dramatic form itself began to fragment and re-form (BIGSBY, 1990, $p$. 11).

One of the so-called minority groups that produced impressive works of art including plays concerning self-representation and questioning of hegemonic values were the African Americans. Theoreticians such as Harry Elam and David Krasner argue that "analyzing African American theater and performance traditions offers insight into how race has operated and continues to operate in American society" (ELAM; KRASNER, 2001, p. 3). African American Theater can be seen as social protest, and as asserted by some African American critics and artists such as W.E.B. Du Bois, Amiri Baraka among others, this protest and revolt must have the purpose of changing black lives, subverting their expected position of subaltern, and fighting against the oppressive conditions they face. By means of theatrical practices many African Americans inserted themselves into history and helped in the creation of an African American identity, because "performance can constitute, contain, and create 'cultural memory'" (ELAM; KRASNER, 2001, p. 9).

\section{AFRICAN AM ERICAN THEATER: LORRAINE HANSBERRY AND A RAISIN IN THE SUN}

The black performer, visibly marked and read by the audiences as "black", enters the stage and negotiates not only the spaces between the stage representation and the social reality but also racial definitions and stereotypes, racial misconceptions, and ambivalences of race (Harry Elam).

One of the biggest changes in the theatrical practices during the XX century was the emergence of companies producing a non-standard theater, "a theatre which would reach out to those for whom reprocesses Broadway plays 
had no relevance" (BIGSBY, 1990, p. 21). This way came out Off-Broadway and Off-Off Broadway productions. "On the whole such groups performed plays unlikely to receive Broadway production and looked for an audience substantially different from that which patronized the uptown theater"(BIGSBY, 1990, p. 22).

Yet at the same time Off and Off-Off Broadway, some regional theaters, and the scatter of small theater groups across the country did explode established views of the potential and function of the theatre and did provide a stage for those excluded as much from the cultural as from the political and economic system. They explored the limits of language and inspected the assumptions behind their own approach to character and plot. They examined the relationship between the theatrical moment and historical event. They explored their own space. They posed questions about the self which perceives. They moved theatre closer to the anxieties, the aspirations, the fears, the social and political urgencies of the people they addressed and whom they invited to share their group solidarity (BIGSBY, 1990, p. 37).

Off and Off-Off Broadway were spaces where minority groups were able to produce and to be recognized for their work. They produced plays talking about their reality, peculiarities, and anxieties; plays that could address their people and serve as a way of self-representation. In this space they could have a theater that talked about and to their people helping in the construction and definition of their identities. But despite the difficulties to produce something out of this space, there were some African American authors who tried to have their plays produced and recognized outside. Although they faced prejudice and discrimination, they wanted to show their realities and to have the chance of producing outside this specific space making their plays watched by all kinds of people, and not only minority groups. They also wanted to make their productions a kind of protest against all the discrimination faced by those in their position of outsiders. One author that must be mentioned while talking about this subject is Lorraine Hansberry.

One of the reasons why Hansberry is an important name in African American theater is the way she opened to African-Americans. She had her play A Raisin in the Sun produced on Broadway in a time when it was not expected to find black people in the audiences of such a place, and much less on the stages. It was not even believed to be possible before she did it. As Lisbeth Lipari stated "A Raisin was not only the first play on Broadway written by an African American, it was also the first Broadway play directed by an African American, Lloyd Richards" (LIPARI, 2004, p. 85) and these were reasons enough for this play to be a complete failure in a society full of prejudice as the north American one. And Lipari goes on affirming that "as Hansberry herself has 
noted, until A Raisin, never before had white people seen black characters talking together outside the presence of whites, nor had audiences, black or white, seen African Americans portrayed on the screen with dignity, humanity, and complexity" (LIPARI, 2004, p. 97).

In the introduction to the edition of the play published in 1994 Robert Nemiroff, to whom Hansberry was married during a period of her life, stated that:

bringing to Broadway the first play by a black (young and unknown) woman, to be directed, moreover, by another unknown black "first," in a theater where black audiences virtually did not exist-and where, in the entire history of the American stage, there had never been a serious commercially successful black drama! (NEM IROFF, 1994, p. 6).

It is needless to say that it was a great challenge to the author. It is also worthwhile remembering that Hansberry was not only the first black woman to have a play produced on Broadway but also the first afro-descendant and the fifth woman to receive the 'Best Play of the Year Award' from the New York Drama Critics (1960) because of this play. It is also important to mention that this was not the only award of the play. In the same year it also received the 'Tony Award for the Best Actor in Play' given to Sidney Poitier, the 'Tony Award for the Best Actress in a Play' given to Claudia McNeil and also the 'Tony Award for the Best Direction of a Play' given to Lloyd Richards (Data from the Internet Broadway Database).

Hansberry's work was not only performed on Broadway, but also turned into a movie released by Columbia Pictures in 1961. It counted on a great cast that included actors who had performed the play in theater - such as Sidney Poitier. She received a special award at the Cannes Festival being the youngest American, first woman, and the first African American to win the award for this 1961 version. Later on, in 1973 Neminoff, together with Charlotte Zaltzberg adapted this work and produced a musical called Raisin that ran on Broadway for nearly three years and won the Tony Award as the best musical. Raisin was revived in 1981, when Claudia McNeil, who had played the character Lena in the original 1959 production, recreated the role in the musical adaptation. To complete the success, another version of the movie was launched in 2004, and in the same year the play was again on the stages of Broadway, in the Royale Theatre. In 2007, the play had the opportunity to be one more time on the stages of Broadway for three months, and last year (2008), it has been adapted to be launched as a made-for-TV movie.

Despite its repercussion, several performances, success in the United States and importance to the African-American studies, I am conscious that the 
play I am dealing with in this paper is not so well-known. As it has not been translated into Portuguese so far, in Brazil it is usually known just among those concerned with the African-American studies. So, I believe that it is important to present in this paper at least an overview of its plot.

\title{
THE DECONSTRUCTION OF THE AMERICAN DREAM
}

\begin{abstract}
Whatever happened to this nation? Or did it ever exist?...did it ever exist with its freedoms and slogans...the buntings, the goldheaded standards, the songs? With Equality, Liberty...In the West they plow under wheat. Where is America? I say it does not exist. And I say that it never existed. It was all but a myth. A great dream of avarice (David Mamet).
\end{abstract}

Alam and Krasner affirm that "African American theater and performance have been and remain powerful sites for creation, application, and even the subversion of notions of blackness and of concepts of African American identity" (ELAM; KRASNER, 2001, p. 5-6). They also assert, based on Stuart Hall's theories that identity is something fluid and always in process and for this reason "[t]here is not simply one African American identity but many African American identities" (ELAM; KRASNER, 2001, p. 13) that are invented or constructed according to the moment and situation experienced. As Stuart Hall argues:

[i]dentities are about questions of using the resources of history, language and culture in the process of becoming rather than being: not "who we are" or "where we have come from" so much as what we might become, how we have been represented and how that bears on how we might represent ourselves (HALL, 1996, p. 4).

Based on this concept, we know that identities are not fixed as they were believed to be during a long time. The Cartesian subject was replaced by a post-colonial one that is known by its fragmentation and fluidity and the African American Theater can help us to understand this new kind of subject and some of the reasons of its changes and fragmentation.

The African American Theater shows the reality of the fragmented subjects who are living in a situation "in-between" two cultures and according to Shannon

[t]his living in at least two worlds while claiming an African-derived identity which refuses to abandon itself by assimilation into mainstream Euro-centric culture is befuddling for many whites who, because of the privilege their white skin carries, have not had to negotiate such dualities (SHANNON, 2001, p. 150). 
This way, the fragmented subjects who take part in the new diasporic movements have to learn how to negotiate between the memories of their homeland and the new reality their face in the colonizer's land. They have also to learn how to handle the cultural, racial, and political differences they face in this new world.

In the article "Uh Tiny Land M ass Just Outside of M y Vocabulary: Expression of Creative Nomadism and Contemporary African American Playwrights", Kimberly Dixon compares the African American expatriate tradition and displacement to nomadic movements. She states that the experience of migration is a shared cultural memory as an individual experiences it. This phenomenon is so common that even non migratory artists are influenced by it. Even those who stayed, discuss this issue in their works because the ones who left to the new world were, and will continue to be, part of their lives. She mentions nomadism not only as a kind of migratory history but also as a frequent preoccupation in postmodernism with themes such as migration, exile, fluid identities, displacement, among others.

In order to reinforce her argument, Dixon quotes Rosi Braidotti's concept of nomadic subjects in which the author states that nomadism, in the sense she is considering it, refers to a "kind of critical consciousness that resists settling into socially coded modes of thought and behavior. Not all nomads are world travelers; some of the greatest trips can take place without physical moving" (DIXON, 2001, p. 214). According to Braidotti's concept the idea of migration or nomadism does not necessarily need a physical displacement, instead of it, it requires a "transmobility of thought and identity" and the subversion of concepts and behavior (DIXON, 2001, p. 215). A nomadic subject, according to her, is an active and critical subject capable of making decisions and questioning patterns, rejecting or subverting the standardized acts when necessary.

Dixon asserts that:

these artists' nomadic subjectivity is in keeping with postmodern and postcolonial discourse on the renegotiation of positionality by the monolithic West and its subjects. No longer are oppressor-oppressed or self-Other precise or permanent identities. Subjects now frequently resist their disadvantaged position, while the monolith now finds it fashionable to examine its own oppression at the hand of individuals or the social systems at large (DIXON, 2001, p. 216).

Despite all the prejudice, oppression, harsh and restrictions, African American writers continue in their struggle against repression and inferiority imposed by the colonizer and, as they use their art productions as a representation of their reality, they constantly work on themes such as displacement, 
migration and shattered identities. What Dixon calls the African American artists' creative nomadism is a movement in pro of self-representation, a kind of struggle for space and resistance to the oppression constantly faced by 'the other'. Based on the aforementioned ideas, creative nomadism does not mean crossing fixed boundaries in the search of supplies, but it is something more subjective. It is an expression of identity and a search for selfrepresentation, voice and subversion of patterns. That's why many works produced by minority groups come on the opposite way in relation to the American Dream, many times deconstructing it. A Raisin in the Sun is a nice example of this kind of work.

In A Raisin in the Sun, Hansberry presented the situation faced by African American people, and also questioned the reality in which they lived. By using some autobiographical references the author tells the story of a black family who suffers a lot of prejudice and discrimination in their search for the ideals presented in the American Dream and shows that this Dream can easily become a nightmare for the immigrants in the land of the opportunity because of attitudes moved by prejudice and discrimination.

The play tells us the story of a Southside Chicago family, the Youngers, full of dreams that are usually deferred. When we are introduced to the family, they are expecting to receive some money from an insurance due to the death of Mr. Younger, and each member of the family has a different plan for it. These plans and dreams deferred bring many struggles to the play, and only by the end of it, a decision is finally made. Mamma - the one responsible for the family since her husband's death - decides that the best option for the money the family would receive would be buying a house for them, but she does so in a white neighborhood, what leads the family to suffer strong prejudice even before they move.

In this play, Hansberry shows the difficulties faced by the African descendents in the USA in their search for a better life. As they are a hybrid of two different cultures, they have fragmented identities, and so, they do not fit among the Americans because they are black and they have African descendents; but they are not Africans either, as they are born and live in America. This way, they are fragmented subjects and for this reason, they suffer constant discrimination and displacement.

Although the American Dream indicates that everyone has the right of happiness and freedom, Hansberry showed that it is not exactly as it seems to be. In this search for happiness and a better life many people can find only prejudice and discrimination. Hansberry criticizes these ideals in her play, showing that, unfortunately, this dream applies only for those who are white, 
Americans, and from a mainstream family, and not exactly for everyone. For several people who take part in the diasporic movements, such as the AfricanAmerican family presented in the play I am working with, the American Dream can turn into a hard nightmare full of disillusions.

\section{REFERENCES}

ASHCROFT, Bill et al. (Eds.). Post-Colonial Studies: The Key Concepts. London: Routledge, 1998.

BHABHA, Homi K. Nation and narration. London: Routledge, 1990.

BHABHA, Homi K. The Location of Culture. London: Routledge, 1994.

BIGSBY, Christopher William Edgar. A Critical Introduction to Twentieth-Century American Drama. Volume 3. New York: Cambridge University Press, 1990.

DIXON, Kimberly. "Uh Tiny Land Mass Just Outside of My Vocabulary: Expression of Creative Nomadism and Contemporary African American Playwrights". In: ELAM, Harry Justin; KRASNER, David. African American Performance and Theater History: A Critical Reader. New York: Oxford University Press, 2001. p. 212-234.

ELAM, Harry. "The Black Performer and the Performance of Blackness". In: ELAM, Harry Justin; KRASNER, David. African American Performance and Theater History: A Critical Reader. New York: Oxford University Press, 2001, p. 288-305.

HALL, Stuart et al. Questions of Cultural Identity. London: Sage Publications, 1996.

HALL, Stuart et al. "The question of cultural identity". In: HAL, Stuart et al. Modernity: An Introduction to Modern Societies. Malden: Blackwell Publishing, 2005, p. 596-634.

HALL, Stuart et al. "Cultural Identity and Diaspora". In: BRAZEL, Jana Evans; M ANNUR, Anita (Ed.). Theorizing Diaspora. Malden: Blackwell Publising, 2006, p. 233-246.

HANSBERRY, Lorraine. A Raisin in the Sun. New York: Random House, 1994.

LIPARI, Lisbeth. "Fearful of the Written Word: White Fear, Black Writing, and Lorraine Hansberry's A Raisin in the Sun Screenplay". In: Quarterly Journal of Speech Vol. 90, No. 1, February 2004. USA: Routledge, 2004, p. 81-102.

M AM ET, David. The Water Engine and Mr. Happiness. New York: Grove Press, 1978.

RICE, Elmer. Elmer Rice Teatro Vivo. Rio de Janeiro: Editora Fundo de Cultura, 1962. Traduzido por Ed Mercedes Zilda Cobas Felgueiras.

SALGUEIRO, Maria Aparecida Andrade. Lorraine Hansberry: Afro-América, Teatro E Autobiografia. In: Feminismos, identidades, e comparativismos: vertentes nas literaturas de língua inglesa. Volume IV. Rio de Janeiro: Europa, 2006, p. 83-88.

SHANNON, Sandra Garrett. "Audience and Africanisms in August Wilson's Dramaturgy". In: ELAM, Harry Justin; KRASNER, David. African American Performance and Theater History: A Critical Reader. New York: Oxford University Press, 2001, p. 149-167.

SINNOTT, Susan. Lorraine Hansberry: award-winning playwright and civil rights activist. USA: Conari Press, 1999. 


\section{WEB REFERENCES}

http://www.ibdb.com/production.php?id=2083 Internet Broadway Database http://www.shubertorganization.com/theatres/ethel_barrymore.asp Theater http://www.npr.org/programs/morning/features/patc/raisin/ Hansberry and her work http://www.theroot.com/views/lorraine-hansberrys-gay-politics http://www.kirjasto.sci.fi/corhans.htm http://wps. ablongman.com/wps/media/ objects/267/273873/janaroim.pdf http://sonsofmalcolm.blogspot.com/2008/05/stokely-carmichael-us-in-1960s.html http://www.britannica.com/EBchecked/topic/254536/Lorraine-Hansberry http://www.encyclopedia.com/doc/1G2-3404702780.html 